\title{
Monocyte Chemoattractant Protein-1 -2518 A/G Single Nucleotide Polymorphism Might Be Associated with Renal Disease and Thrombocytopenia of SLE
}

\author{
Piotr Piotrowski, ${ }^{1,2}$ Margarita Lianeri, ${ }^{1}$ Robert Gasik, ${ }^{1,3}$ Andrzej Roszak, ${ }^{1,4}$ \\ Marzena Olesińska, ${ }^{3}$ and Paweł P. Jagodziński ${ }^{1}$ \\ ${ }^{1}$ Department of Biochemistry and Molecular Biology, Poznań University of Medical Sciences, 6 Święcickiego St., 60-781 Poznań, Poland \\ ${ }^{2}$ Medical Research Centre, Polish Academy of Sciences, Warsaw, Poland \\ ${ }^{3}$ Institute of Rheumatology, Warsaw, Poland \\ ${ }^{4}$ Department of Radiotherapy and Gynecological Oncology, Greater Poland Cancer Centre, 15 Garbary St., 61-866 Poznan, Poland
}

Correspondence should be addressed to Paweł P. Jagodziński, pjagodzi@am.poznan.pl

Received 30 November 2009; Revised 13 February 2010; Accepted 14 March 2010

Academic Editor: Timothy B. Niewold

Copyright (C) 2010 Piotr Piotrowski et al. This is an open access article distributed under the Creative Commons Attribution License, which permits unrestricted use, distribution, and reproduction in any medium, provided the original work is properly cited.

There is conflicting evidence on the contribution of the MCP-1 -2518 A>G (rs 1024611) polymorphism to SLE incidence and clinical manifestations. We examined the prevalence of the MCP-1 -2518 A>G polymorphism in SLE patients $(n=199)$ and controls $(n=250)$ in Poland. We did not observe a significant difference in the distribution of MCP-1 -2518 A $>$ G polymorphic variants in patients with SLE and healthy individuals. However, we found an association between the GG versus AG and AA genotypes as well as the AG and GG versus AA genotypes with renal manifestations of SLE OR $=3.614(1.123-11.631, P=0.0345)$ and $\mathrm{OR}=2.297(1.301-4.057, P=0.0046)$, respectively. We also observed that the MCP-1 AG and GG -genotypes contribute to the occurrence of thrombocytopenia in SLE patients $\mathrm{OR}=2.618(1.280-5.352, P=0.0089)$. Our observations indicate that either MCP-1 $-2518 \mathrm{G}$ variant can be associated with some clinical findings in patients with SLE.

\section{Introduction}

Systemic lupus erythematosus (SLE) is a chronic and progressive multisystem autoimmune connective tissue disorder, which is characterized by immune-mediated host tissue destruction [1]. Occupational exposure, chemicals, drugs, food, as well as viral and bacterial infectious agents can contribute significantly to changes in the immune system $[2,3]$.

Immune cells from patients with SLE exhibit various defects including skewed cytokine production, a decrease in cytotoxic $\mathrm{T}$ cell function, and an increase in the humoral response [4-7]. The defective function of $\mathrm{CD} 4^{+} \mathrm{T}$ cells associated with abnormal stimulation of $\mathrm{B}$ cells causes abundant autoantibody production $[4,6]$. These autoantibodies form immune complexes with antigens on the patient's own cells and are accumulated in the skin, synovium, lungs, renal glomeruli, and other organs and tissues. This results in the clinical presentation of SLE $[1,8]$.

The pathogenesis of SLE remains unclear, though there is much evidence demonstrating the involvement of genetic factors in the incidence of this autoimmune disease [9-13]. The genetic background contributing to SLE development includes, in particular, genes encoding disparate proteins that control immune system pathways $[9,10,13]$.

The monocyte chemoattractant protein 1 (MCP-1), currently also designated CCL2, belongs to the family of chemotactic cytokines. MCP-1 functions as a potent agonist for monocytes, memory T cells, and basophils [14]. Evidence in animal and human studies suggests a significant role of MCP1 in the progression of glomerular and tubulointerstitial injuries and glomerulonephriti in patients with SLE [15-19].

It has been demonstrated that the MCP-1 $-2518 \mathrm{~A}>\mathrm{G}$ (rs 1024611) transition in the promoter region may modulate 
the levels of MCP-1 expression [20, 21]. The MCP-1 -2518 $\mathrm{G}$ allele, compared to the $-2518 \mathrm{~A}$ allele, is linked with increased production of both MCP-1 transcript and protein $[20,21]$. Involvement of the MCP-1 $-2518 \mathrm{~A}>\mathrm{G}$ promoter polymorphism in SLE development and its contribution to some clinical manifestations of SLE remains controversial [22-28]. We analysed the distribution of functional MCP-1 $-2518 \mathrm{~A}>\mathrm{G}$ polymorphic variants in SLE patients $(n=199)$ and controls $(n=250)$.

\section{Patients and Methods}

2.1. Patients and Controls. One hundred ninety nine (women only) patients fulfilling the American College of Rheumatology Classification criteria for SLE $[29,30]$ were chosen for investigation at Institute of Rheumatology in Warsaw, Poland (Table 1). Two hundred and fifty healthy women were included as controls. The protocol of the study was approved by the Local Ethical Committee of Poznań University of Medical Sciences. Written agreement was obtained from patients and controls. All participating subjects were of Polish and Caucasian origin. The mean age of SLE patients at diagnosis was $36 \pm 12$ years, and of controls, $35 \pm 11$ years.

2.2. Genotyping. DNA was isolated from peripheral white blood cells employing a standard salting out procedure. The presence of the MCP-1 -2518 A $>G$ (rs 1024611) polymorphic variant was identified by polymerase chain reaction-restriction fragment length polymorphism (PCRRFLP). PCR was carried out using primer pair $5^{\prime}$-CTTTCCCTTGTGTGTCCCC-3' and 5'-TTACTCCTTTTCTCCCCAACC- $3^{\prime}$. The PCR-amplified fragments of MCP-1 that were $940 \mathrm{bp}$ in length were isolated and subjected to digestion with endonuclease PvuII (CAG/CTG) (New England Biolabs, Ipswich, USA). The MCP-1 $-2518 \mathrm{G}$ allele was cleaved into $650 \mathrm{bp}$ and $290 \mathrm{bp}$ fragments; whereas the MCP-1 -2518 A allele remained uncut. DNA fragments were separated by electrophoresis on $2 \%$ agarose gel and visualized by ethidium bromide staining. Presence of the MCP-1 polymorphism was additionally confirmed by commercial sequencing analysis.

2.3. Statistical Analysis. The prevalence of genotypes in patients and controls was examined for deviation from Hardy-Weinberg equilibrium. Uncorrected $\mathrm{Chi}^{2}$ test was employed to examine differences in genotypic and allelic distribution between patients and controls. Moreover, the Odds Ratio (OR) and 95\% Confidence Intervals (95\% CI) were calculated. A $P$-value $<0.05$ was considered statistically significant. Associations between clinical manifestations, production of autoantibodies, and polymorphism distribution in patients with SLE were determined by Fisher exact test. The Mann-Whitney test for nonparametric data was used to determine the statistical difference in SLE disease activity index (SLEDAI) [31] between MCP-1 GG, AG, and AA genotype groups. Power analysis was performed using uncorrected $\mathrm{Chi}^{2}$ test, which is available at an online internet service: http://biostat.mc.vanderbilt.edu/twiki/bin/view/Main/ PowerSampleSize.

\section{Results}

3.1. Distribution of MCP-1 -2518 A>G Genotypes and Alleles in SLE Patients and Healthy Individuals. Genotype analysis of the MCP-1 -2518 A>G polymorphism did not reveal a significant deviation form Hardy-Weinberg equilibrium in any group. We did not observe a significant difference in the prevalence of the MCP-1 -2518 A $>$ G polymorphic variant in patients with SLE and healthy individuals (Table 2). OR for SLE patients with the GG genotype was 0.8629 (95\% CI $=0.4428-1.682, P=0.6647)$, and $\mathrm{OR}$ of the GG and AG genotypes was $0.9320(95 \% \mathrm{CI}=0.6421-1.353, P=0.7111)$ (Table 2). The power of this study amounted to $7.0 \%$ for the GG genotype and $6.6 \%$ for the GG and GA genotypes. We also did not observe a difference in the distribution of alleles between patients and controls. OR for the MCP-1 $2518 \mathrm{G}$ allele frequency was $0.9314(95 \% \mathrm{CI}=0.6963-1.246$, $P=0.6320)$.

3.2. Association of MCP-1 -2518 A>G Genotypes with Clinical Symptoms of SLE. Since the previous studies indicated the contribution of either MCP-1 -2518 GG or AG genotypes to some clinical SLE manifestations [22, 23, 28], we assessed the association of these genotypes to clinical findings in our investigated group. We observed the association between the GG versus $A G$ and $A A$ genotypes and $A G$ and $G G$ versus AA genotypes with renal manifestations of SLE OR $=3.614(1.123-11.631, P=0.0345)$ and $\mathrm{OR}=2.297(1.301-$ 4.057, $P=0.0046$ ), respectively (Table 1$)$. However, these $P$ values did not remain statistically significant after Bonferroni correction $\left(P_{\text {corr }}=0.621 ; P_{\text {corr }}=0.0828\right.$, resp. $)$. We observed an association between the GG versus AA genotypes with renal manifestations OR $=4.923(1.483-16.343, P=0.0067)$ $\left(P_{\text {corr }}=0.1206\right)($ Table 1$)$. There was also an association of the MCP-1 (AG and GG versus AA) genotypes with occurrence of thrombocytopenia $\mathrm{OR}=2.618(1.280-5.352$, $P=0.0089)\left(P_{\text {corr }}=0.1602\right)$ in SLE patients (Table 1$)$. We did not find a significant association between the GG genotype or G allele with the presence of anti-dsDNA, antiSmith, anti-snRNP, anti-Ro, anti-Scl-70, or antiphospholipid antibodies. There were also no significant differences in SLEDAI at diagnosis between MCP-1 GG, AG, and AA genotype groups.

\section{Discussion}

Completion of the human genome project revealed the existence of approximately ten million single nucleotide polymorphisms (SNPs). However, the role of SNPs in states of either health or sickness remains under investigation [32].

To date, the MCP-1 $-2518 \mathrm{~A}>\mathrm{G}$ polymorphism has been associated with coronary artery disease, nonfamilial idiopathic dilated cardiomyopathy, carotid atherosclerosis in patients with type 2 diabetes, myocardial infarction, ischemic heart disease, and hypertension [33-38]. Moreover, the MCP-1 $-2518 \mathrm{G}$ variant may also contribute to ocular Behçet's disease, adult and juvenile type of rheumatoid arthritis, systemic sclerosis, and psoriasis [39-43]. 
TABLE 1: Association of the MCP-1 -2518 A $>$ G polymorphism with clinical manifestation in patients with SLE.

\begin{tabular}{|c|c|c|c|c|}
\hline \multirow{2}{*}{ Characteristic } & \multicolumn{4}{|c|}{ Genotypes distribution } \\
\hline & $\mathrm{A} / \mathrm{A}(103)^{(\mathrm{a})}$ & $\mathrm{A} / \mathrm{G}(80)^{(\mathrm{a})}$ & $\mathrm{G} / \mathrm{G}(16)^{(\mathrm{a})}$ & Odds ratio $(95 \% \mathrm{CI}), P^{(\mathrm{e})}$ \\
\hline Malar rash & 46 & 39 & 6 & \\
\hline Discoid rash & 32 & 23 & 5 & \\
\hline Photosensitivity & 47 & 38 & 7 & \\
\hline Oral ulcers & 41 & 32 & 6 & \\
\hline Arthritis & 59 & 42 & 8 & \\
\hline Serositis & 18 & 13 & 3 & \\
\hline Renal & 39 & 44 & 12 & $\begin{array}{l}3.614(1.123-11.631, P=0.0345)^{(\mathrm{b})} \\
2.297(1.301-4.057, P=0.0046)^{(\mathrm{c})} \\
4.923(1.483-16.343, P=0.0067)^{(\mathrm{d})}\end{array}$ \\
\hline Neurologic symptoms & 19 & 16 & 4 & \\
\hline Hematologic symptoms & 28 & 23 & 6 & \\
\hline Thrombocytopenia & 14 & 23 & 5 & $2.618(1.280-5.352, P=0.0089)^{(\mathrm{c})}$ \\
\hline Leukopenia & 21 & 16 & 3 & \\
\hline Immunologic symptoms & 51 & 43 & 7 & \\
\hline ANA & 103 & 80 & 16 & \\
\hline
\end{tabular}

(a) represents the absolute number of positive patients for $\mathrm{A} / \mathrm{A}, \mathrm{A} / \mathrm{G}, \mathrm{A} / \mathrm{G}$ genotypes, respectively.

Comparison genotype $^{(b)}(\mathrm{G} / \mathrm{G}$ versus $\mathrm{A} / \mathrm{A}$ and $\mathrm{A} / \mathrm{G}) ;{ }^{(\mathrm{c})}(\mathrm{G} / \mathrm{G}$ and $\mathrm{A} / \mathrm{G}$ versus $\mathrm{A} / \mathrm{A}){ }^{(\mathrm{d})}(\mathrm{G} / \mathrm{G}$ versus $\mathrm{A} / \mathrm{A})$, between patients with and patients without a manifestation was performed by ${ }^{(e)}$ Fisher exact test.

TABLE 2: Association of the MCP-1 -2518 A>G polymorphisms in SLE patients and controls.

\begin{tabular}{|c|c|c|c|c|c|}
\hline MCP-1 -2518 A>G (rs1024611) & SLE $n=199(\%)$ & Controls $n=250(\%)$ & OR & $95 \% \mathrm{CI}$ & ${ }^{(\mathrm{d})} P$-value \\
\hline \multicolumn{6}{|l|}{ Genotype frequency } \\
\hline $\mathrm{A} / \mathrm{A}$ & $103(51.8)$ & $125(50.0)$ & & & \\
\hline $\mathrm{A} / \mathrm{G}$ & $80(40.2)$ & $102(40.8)$ & & & \\
\hline G/G & $16(8.0)$ & $23(9.2)$ & $0.8629^{(a)}$ & $0.4428-1.682$ & 0.6647 \\
\hline $\mathrm{A} / \mathrm{G}+\mathrm{G} / \mathrm{G}$ & $96(48.2)$ & $125(50.0)$ & $0.9320^{(b)}$ & $0.6421-1.353$ & 0.7111 \\
\hline \multicolumn{6}{|l|}{ Allele frequency } \\
\hline A & $286(71.9)$ & $352(70.4)$ & & & \\
\hline G & $112(28.1)$ & $148(29.6)$ & $0.9314^{(\mathrm{c})}$ & $0.6963-1.246$ & 0.6320 \\
\hline
\end{tabular}

The Odds ratio was calculated for patients ${ }^{(a)}$ (G/G genotype versus $\mathrm{A} / \mathrm{G}$ and $\mathrm{A} / \mathrm{A}$ genotypes); ${ }^{(\mathrm{b})}$ (G/G and $\mathrm{A} / \mathrm{G}$ genotype versus $\mathrm{A} / \mathrm{A}$ genotype).

We also determined the OR for the patients' minor allele ${ }^{\text {(c) }}$ ( $\mathrm{G}$ versus A allele); (d) uncorrected $\mathrm{Chi}^{2}$.

Reports on the contribution of the MCP-1 -2518 A $>\mathrm{G}$ polymorphism to SLE incidence and clinical manifestations have been inonsistent $[22-28,44,45]$. We did not observe differences in the distribution of the MCP-1 -2518 A $>\mathrm{G}$ polymorphic variant between patients with SLE and healthy individuals; however this may be due to the low power of our investigation.

There have been no reports of a contribution of either the MCP-1 AG or GG genotype to SLE incidence in African American, Spanish, Korean, and Mexican cohorts [23-26, 44, 45]. By contrast, Tucci et al. showed a significant association of the MCP-1 AG and GG genotypes to SLE incidence in patients from North America [22]. Moreover, Brown et al. found that Caucasians bearing the MCP-1 $-2518 \mathrm{G}$ allele exhibited a significantly increased risk of developing SLE [26].

These conflicting reports on the effect of the MCP$1-2518 \mathrm{~A}>\mathrm{G}$ polymorphism to the incidence of SLE in various populations may be due to differences in the racial heterogeneity of the examined groups. This disparity may also have resulted from each population's exposure to distinct environmental factors, which may act in synergy with the MCP-1 -2518 A $>$ G polymorphism to change the risk of SLE incidence among the studied populations [3].

We observed that the MCP-1 G/G and A/G genotypes contribute to renal manifestations of the disease. A correlation between the MCP-1 $-2518 \mathrm{G}$ allele and nephritis was also observed in a North American SLE cohort [22]. Furthermore, the MCP-1 -2518 G allele was associated with cutaneous vasculitis in a Spanish SLE group [23], arthritis in Chinese adults with SLE [28] and the presence of antidsDNA and antiphospholipid antibodies in Mexican patients with SLE [45].

The MCP-1 -2518 A $>\mathrm{G}$ polymorphism is located at a relatively proximal position to the major transcriptional start site of the MCP-1 gene. Rovin et al. cloned the distal regulatory region of a luciferase reporter gene, including the MCP-1 $-2518 \mathrm{~A}>\mathrm{G}$ polymorphic variant upstream of 
the reporter gene [20]. They indicated that peripheral blood mononuclear cells with either the MCP-1 AG or GG genotype demonstrated increased interleukin 1 beta-induced MCP-1 transcription compared to cells with genotype AA [20]. Moreover, Fenoglio et al. also showed that Alzheimer's disease patients bearing at least one MCP-1-2518 G allele exhibited a significant increase of MCP-1 levels in blood plasma [21].

It has been reported that different renal cells, including glomerular endothelial, mesangial, and tubular epithelial cells, are able to biosynthesize MCP-1 in response to immune complexes or some proinflammatory cytokines [46-48]. This MCP-1 production by renal cells can be enhanced by the MCP-1 -2518 G variant leading to the renal manifestations of SLE observed in both our investigation and other studies [22].

We also found that the MCP-1 GG and AG genotypes are associated with thrombocytopenia. An increase in serum levels of MCP-1 has previously been linked to elevated soluble CD40L in patients with autoimmune thrombocytopenic purpura [49].

The platelets of SLE patients are perpetually activated, and these patients exhibit an increase of soluble CD40L levels in the blood plasma $[50,51]$. The interaction of CD40L from activated platelets with CD40 on endothelial cells induces an inflammatory reaction in the endothelium leading to the secretion of chemokines, including MCP-1 [52]. This may produce signals for the recruitment and extravasations of macrophages, which are able to interact with anti-platelet antibodies complexed with the platelets, which may lead to platelet destruction [49].

Our genetic investigation suggests that the MCP-1 -2518 $\mathrm{G}$ variant can contribute to some clinical findings in patients with SLE. However, to more precisely evaluate the effect of the MCP-1 -2518 G variant on SLE manifestations, further examination of this variant's distribution in other sample populations is required.

\section{Acknowledgment}

This work was supported by A grant no. 502-01-0112418207474, Poznań University of Medical Sciences.

\section{References}

[1] I. Sekigawa, T. Naito, K. Hira, et al., "Possible mechanisms of gender bias in SLE: a new hypothesis involving a comparison of SLE with atopy," Lupus, vol. 13, no. 4, pp. 217-222, 2004.

[2] L. A. Love, "New environmental agents associated with lupuslike disorders," Lupus, vol. 3, no. 6, pp. 467-471, 1994.

[3] A. Jönsen, A. Bengtsson, O. Nived, L. Truedsson, and G. Sturfelt, "Gene-environment interactions in the aetiology of systemic lupus erythematosus," Autoimmunity, vol. 40, no. 8, pp. 613-617, 2007.

[4] J. C. Crispín and G. C. Tsokos, "Novel molecular targets in the treatment of systemic lupus erythematosus," Autoimmunity Reviews, vol. 7, no. 3, pp. 256-261, 2008.

[5] R. Januchowski, M. Wudarski, H. Chwalińska-Sadowska, and P. P. Jagodzinski, "Prevalence of ZAP-70, LAT, SLP-76, and DNA methyltransferase 1 expression in $\mathrm{CD}^{+} \mathrm{T}$ cells of patients with systemic lupus erythematosus," Clinical Rheumatology, vol. 27, no. 1, pp. 21-27, 2008.

[6] W. Stohl, S. Metyas, S. M. Tan, et al., "B lymphocyte stimulator overexpression in patients with systemic lupus erythematosus: longitudinal observation," Arthritis and Rheumatism, vol. 48, no. 12, pp. 3475-3486, 2003.

[7] G. Gröndal, I. Gunnarsson, J. Rönnelid, S. Rogberg, L. Klareskog, and I. Lundberg, "Cytokine production, serum levels and disease activity in systemic lupus erythematosus," Clinical and Experimental Rheumatology, vol. 18, no. 5, pp. 565-570, 2000.

[8] L. Truedsson, A. A. Bengtsson, and G. Sturfelt, "Complement deficiencies and systemic lupus erythematosus," Autoimmunity, vol. 40, no. 8, pp. 560-566, 2007.

[9] M. Wong and B. P. Tsao, "Current topics in human SLE genetics," Springer Seminars in Immunopathology, vol. 28, no. 2, pp. 97-107, 2006.

[10] J. B. Harley, J. A. Kelly, and K. M. Kaufman, "Unraveling the genetics of systemic lupus erythematosus," Springer Seminars in Immunopathology, vol. 28, no. 2, pp. 119-130, 2006.

[11] G. Hom, R. R. Graham, B. Modrek, et al., "Association of systemic lupus erythematosus with C8orf13-BLK and ITGAM-ITGAX," New England Journal of Medicine, vol. 358, no. 9, pp. 900-909, 2008.

[12] International Consortium for Systemic Lupus Erythematosus Genetics (SLEGEN), J. B. Harley, M. E. Alarcón-Riquelme, et al., "Genome-wide association scan in women with systemic lupus erythematosus identifies susceptibility variants in ITGAM, PXK, KIAA1542 and other loci," Nature Genetics, vol. 40, no. 2, pp. 204-210, 2008.

[13] L. Prokunina and M. Alarcon-Riquelme, "The genetic basis of systemic lupus erythematosus -knowledge of today and thoughts for tomorrow," Human Molecular Genetics, vol. 13, no. 1, pp. R143-R148, 2004.

[14] I. F. Charo and M. B. Taubman, "Chemokines in the pathogenesis of vascular disease," Circulation Research, vol. 95, no. 9, pp. 858-866, 2004.

[15] R. A. K. Stahl, F. Thaiss, M. Disser, U. Helmchen, K. Hora, and D. Schlöndorff, "Increased expression of monocyte chemoattractant protein-1 in anti-thymocyte antibodyinduced glomerulonephriti," Kidney International, vol. 44, no. 5, pp. 1036-1047, 1993.

[16] B. H. Rovin, N. Doe, and L. C. Tan, "Monocyte chemoattractant protein-1 levels in patients with glomerular disease," American Journal of Kidney Diseases, vol. 27, no. 5, pp. 640-646, 1996.

[17] A. Saitoh, Y. Suzuki, M. Takeda, K. Kubota, K. Itoh, and Y. Tomino, "Urinary levels of monocyte chemoattractant protein (MCP)-1 and disease activity in patients with IgA nephropathy," Journal of Clinical Laboratory Analysis, vol. 12, no. 1, pp. 1-5, 1998.

[18] V. R. Kelley and B. H. Rovin, "Chemokines: therapeutic targets for autoimmune and inflammatory renal disease," Springer Seminars in Immunopathology, vol. 24, no. 4, pp. 411-421, 2003.

[19] B. H. Rovin and L. T. Phan, "Chemotactic factors and renal inflammation," American Journal of Kidney Diseases, vol. 31, no. 6, pp. 1065-1084, 1998.

[20] B. H. Rovin, L. Lu, and R. Saxena, "A novel polymorphism in the MCP-1 gene regulatory region that influences MCP-1 expression," Biochemical and Biophysical Research Communications, vol. 259, no. 2, pp. 344-348, 1999.

[21] C. Fenoglio, D. Galimberti, C. Lovati, et al., "MCP-1 in Alzheimer's disease patients: A-2518G polymorphism and 
serum levels," Neurobiology of Aging, vol. 25, no. 9, pp. 1169-1173, 2004.

[22] M. Tucci, E. V. Barnes, E. S. Sobel, et al., "Strong association of a functional polymorphism in the monocyte chemoattractant protein 1 promoter gene with lupus nephritis," Arthritis and Rheumatism, vol. 50, no. 6, pp. 1842-1849, 2004.

[23] F. Aguilar, M. F. González-Escribano, J. Sánchez-Román, and A. Núñez-Roldán, "MCP-1 promoter polymorphism in Spanish patients with systemic lupus erythematosus," Tissue Antigens, vol. 58, no. 5, pp. 335-338, 2001.

[24] S.-Y. Hwang, M.-L. Cho, B. Park, et al., "Allelic frequency of the MCP-1 promoter -2518 polymorphism in the Korean population and in Korean patients with rheumatoid arthritis, systemic lupus erythematosus and adult-onset Still's disease," European Journal of Immunogenetics, vol. 29, no. 5, pp. 413-416, 2002.

[25] H. L. Kim, D.-S. Lee, S. H. Yang, et al., "The polymorphism of monocyte chemoattractant protein-1 is associated with the renal disease of SLE," American Journal of Kidney Diseases, vol. 40, no. 6, pp. 1146-1152, 2002.

[26] K. S. Brown, E. Nackos, S. Morthala, L. E. Jensen, A. S. Whitehead, and J. M. Von Feldt, "Monocyte chemoattractant protein-1: plasma concentrations and $\mathrm{A}(-2518) \mathrm{G}$ promoter polymorphism of its gene in systemic lupus erythematosus," Journal of Rheumatology, vol. 34, no. 4, pp. 740-746, 2007.

[27] C. H. Liao, T. C. Yao, H. T. Chung, L. C. See, M. L. Kuo, and J. L. Huang, "Polymorphisms in the promoter region of RANTES and the regulatory region of monocyte chemoattractant protein-1 among Chinese children with systemic lupus erythematosus," Journal of Rheumatology, vol. 31, no. 10, pp. 2062-2067, 2004.

[28] D. Q. Ye, Y. S. Hu, X. P. Li, et al., "The correlation between monocytes chemoattractant protein-1 and the arthritis of sytemic lupus erythematosus among Chinese," Archives of Dermatological Research, vol. 296, no. 8, pp. 366-371, 2005.

[29] E. M. Tan, A. S. Cohen, J. F. Fries, et al., "The 1982 revised criteria for the classification of systemic lupus erythrematosus," Arthritis and Rheumatism, vol. 25, no. 11, pp. 1271-1277, 1982.

[30] M. C. Hochberg, "Updating the American College of Rheumatology revised criteria for the classification of systemic lupus erythematosus," Arthritis and Rheumatism, vol. 40, no. 9, p. 1725, 1997.

[31] C. Bombardier, D. D. Gladman, M. B. Urowitz, D. Caron, and C. H. Chang, "Derivation of the SLEDAI: a disease activity index for lupus patients. The Committee on Prognosis Studies in SLE," Arthritis and Rheumatism, vol. 35, no. 6, pp. 630-640, 1992.

[32] International HapMap Consortium, K. A. Frazer, D. G. Ballinger, et al., "A second generation human haplotype map of over 3.1 million SNPs," Nature, vol. 449, no. 7164, pp. 851-861, 2007.

[33] C. Szalai, J. Duba, Z. Prohászka, et al., "Involvement of polymorphisms in the chemokine system in the susceptibility for coronary artery disease (CAD). Coincidence of elevated Lp(a) and MCP-1 -2518 G/G genotype in CAD patients," Atherosclerosis, vol. 158, no. 1, pp. 233-239, 2001.

[34] A. Ogimoto, H. Okayama, T. Nagai, et al., "Association of monocyte chemoattractant protein 1 gene polymorphism with susceptibility to nonfamilial idiopathic dilated cardiomyopathy," Journal of Cardiology, vol. 54, no. 1, pp. 66-70, 2009.

[35] R. Jemaa, H. Rojbani, A. Kallel, et al., "Association between the $-2518 \mathrm{G} / \mathrm{A}$ polymorphism in the monocyte chemoattractant protein-1 (MCP-1) gene and myocardial infarction in
Tunisian patients," Clinica Chimica Acta, vol. 390, no. 1-2, pp. 122-125, 2008.

[36] M. Bucova, J. Lietava, F. Mrazek, et al., "The MCP-1 -2518 $(\mathrm{A} / \mathrm{G})$ single nucleotide polymorphism is associated with ischemic heart disease and myocardial infarction in men in the Slovak population," Bratislavské Lekárske Listy, vol. 110, no. 7, pp. 385-389, 2009.

[37] S. Yuasa, T. Maruyama, Y. Yamamoto, et al., "MCP-1 gene A-2518G polymorphism and carotid artery atherosclerosis in patients with type 2 diabetes," Diabetes Research and Clinical Practice, vol. 86, no. 3, pp. 193-198, 2009.

[38] R. Jemaa, S. Ben Ali, A. Kallel, et al., "Association between the $-2518 \mathrm{G} / \mathrm{A}$ polymorphism in the monocyte chemoattractant protein-1 (MCP-1) gene and hypertension in Tunisian patients," Clinical Biochemistry, vol. 42, no. 1-2, pp. 34-37, 2009.

[39] S. Hou, P. Yang, L. Du, et al., "Monocyte chemoattractant protein-1 -2518 A/G single nucleotide polymorphism in Chinese Han patients with ocular Behçet's disease," Human Immunology, vol. 71, no. 1, pp. 79-82, 2010.

[40] A. R. Ozyürek, D. Gürses, Z. Ulger, E. Levent, A. R. Bakiler, and A. Berdeli, "Allelic frequency of the MCP-1 promoter -2518 polymorphism in the Turkish population and in Turkish patients with juvenile rheumatoid arthritis," Clinical Rheumatology, vol. 26, no. 4, pp. 546-550, 2007.

[41] S. Karrer, A. K. Bosserhoff, P. Weiderer, et al., "The -2518 promotor polymorphism in the MCP-1 gene is associated with systemic sclerosis," Journal of Investigative Dermatology, vol. 124, no. 1, pp. 92-98, 2005.

[42] M. F. González-Escribano, B. Torres, F. Aguilar, et al., "MCP-1 promoter polymorphism in Spanish patients with rheumatoid arthritis," Human Immunology, vol. 64, no. 7, pp. 741-744, 2003.

[43] L. Wang, L. Yang, L. Gao, T. W. Gao, W. Li, and Y. F. Liu, "A functional promoter polymorphism in monocyte chemoattractant protein-1 is associated with psoriasis," International Journal of Immunogenetics, vol. 35, no. 1, pp. 45-49, 2008.

[44] E. Sánchez, J. M. Sabio, J. L. Callejas, et al., "Association study of genetic variants of pro-inflammatory chemokine and cytokine genes in systemic lupus erythematosus," $B M C$ Medical Genetics, vol. 7, article 48, 2006.

[45] G. Lima, E. Soto-Vega, Y. Atisha-Fregoso, et al., "MCP-1, RANTES, and SDF-1 polymorphisms in Mexican patients with systemic lupus erythematosus," Human Immunology, vol. 68, no. 12, pp. 980-985, 2007.

[46] M. Baggiolini, B. Dewald, and B. Moser, "Interleukin-8 and related chemotactic cytokines-CXC and CC chemokines," Advances in Immunology, vol. 55, pp. 97-179, 1994.

[47] A. Sica, J. M. Wang, F. Colotta, et al., "Monocyte chemotactic and activating factor gene expression induced in endothelial cells by IL-1 and tumor necrosis factor," Journal of Immunology, vol. 144, no. 8, pp. 3034-3038, 1990.

[48] J. A. Satriano, K. Hora, Z. Shan, E. R. Stanley, T. Mori, and D. Schlondorff, "Regulation of monocyte chemoattractant protein-1 and macrophage colony stimulating factor- 1 by IFN-gamma, tumor necrosis factor-alpha, IgG aggregates, and cAMP in mouse mesangial cells," Journal of Immunology, vol. 150, no. 5, pp. 1971-1978, 1993.

[49] M. Nagahama, S. Nomura, S. Kanazawa, Y. Ozaki, H. Kagawa, and S. Fukuhara, "Significance of chemokines and soluble CD40 ligand in patients with autoimmune thrombocytopenic purpura," European Journal of Haematology, vol. 69, no. 5-6, pp. 303-308, 2002. 
[50] K. N. Ekdahl, A. A. Bengtsson, J. Andersson, et al., "Thrombotic disease in systemic lupus erythematosus is associated with a maintained systemic platelet activation," British Journal of Haematology, vol. 125, no. 1, pp. 74-78, 2004.

[51] K. Kato, E. Santana-Sahagún, L. Z. Rassenti, et al., "The soluble CD40 ligand sCD154 in systemic lupus erythematosus," Journal of Clinical Investigation, vol. 104, no. 7, pp. 947-955, 1999.

[52] V. Henn, J. R. Slupsky, M. Gräfe, et al., "CD40 ligand on activated platelets triggers an inflammatory reaction of endothelial cells," Nature, vol. 391, no. 6667, pp. 591-594, 1998. 


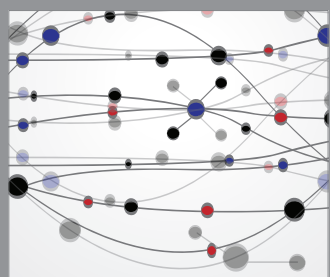

The Scientific World Journal
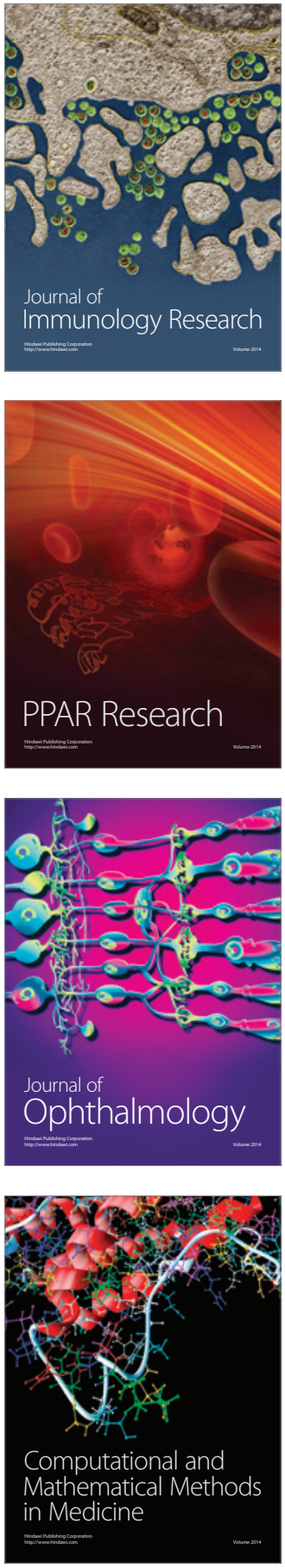

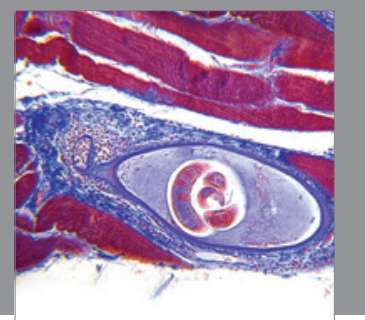

Gastroenterology

Research and Practice
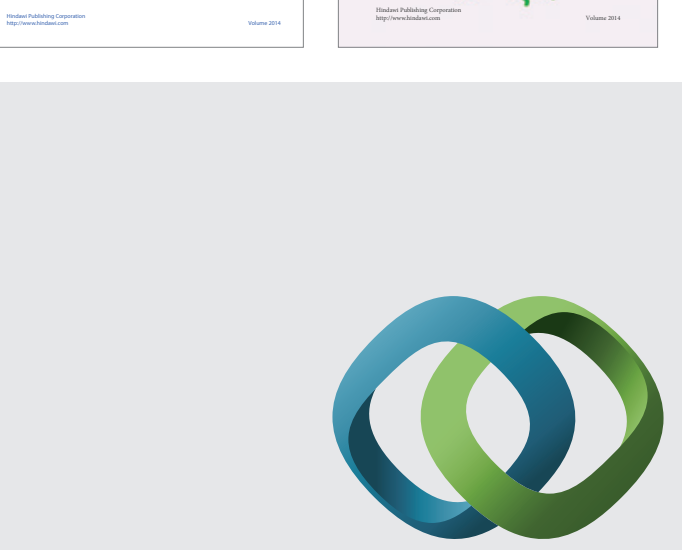

\section{Hindawi}

Submit your manuscripts at

http://www.hindawi.com
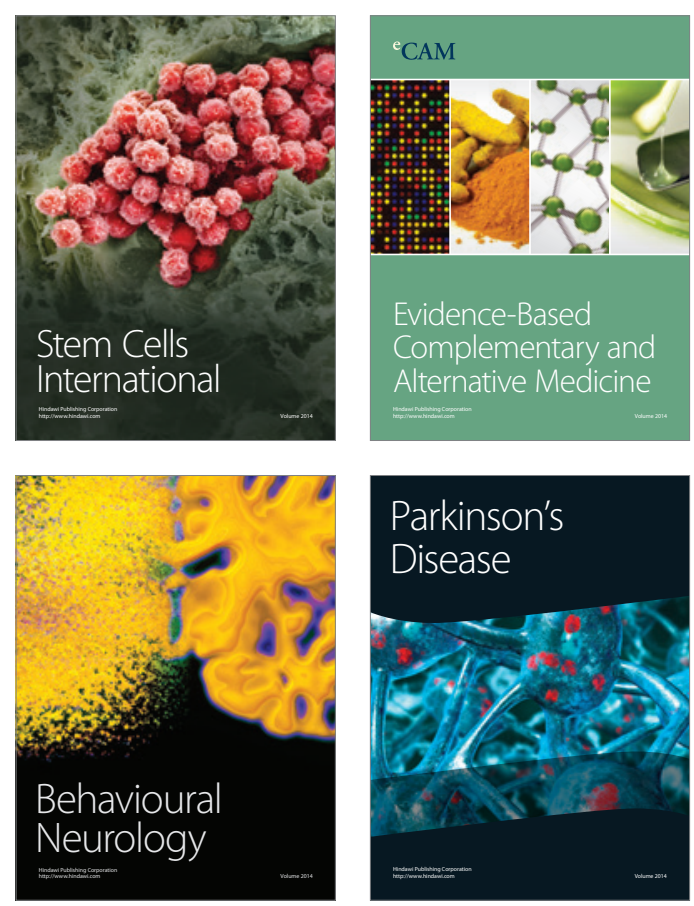

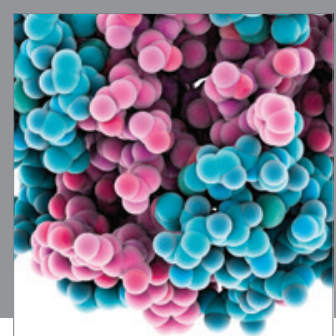

Journal of
Diabetes Research

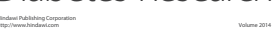

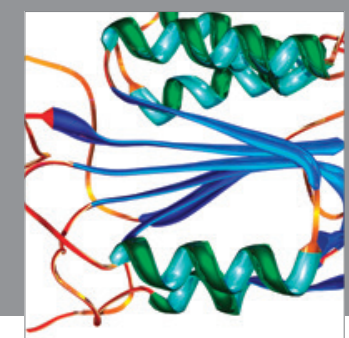

Disease Markers
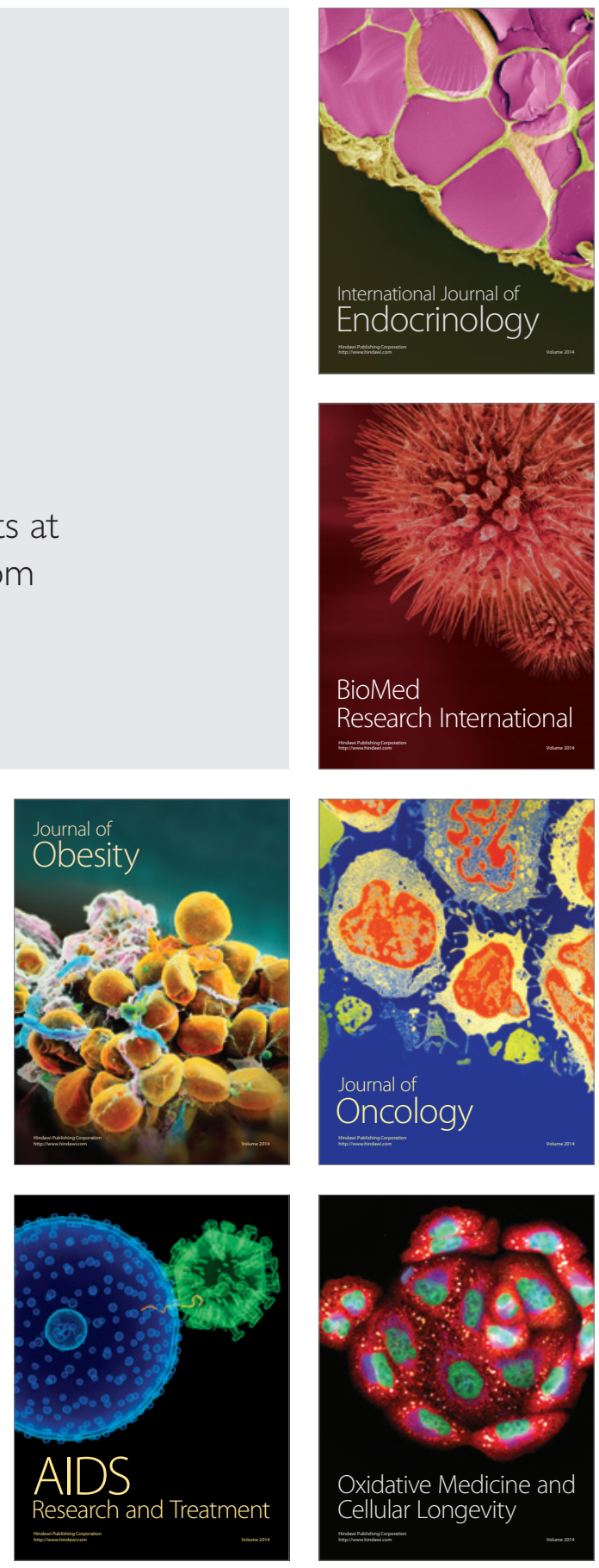